\section{Inspiroiva käsikirja esimiestyön alkutaipaleelle}

\author{
Tarja Surakka \& Nina Laine (2011): Käsikirja ammattimaiseen \\ esimiestyöhön. Taurusmedia.
}

Tuntuu siltä, että johtamisoppaita ja erilaisten gurujen mietelmiä johtamisesta ilmestyy joka vuosi kiihtyvällä tahdilla. Yleensä kirjoittajien näkökulma pyrkii olemaan uusi ja vallankumouksellinen. Jonkin uuden käsitteen tai -ismin läpi tarkastellaan esimiestyön ja johtamisen kenttää. Monesti näitä kirjoja lukiessa tulee sama tunne kuin eräällä henkilöllä Molierin näytelmässä. Hän luki uutta kirjallisuuden lajia, ja tokaisi kumppanilleen innoissaan: "Hei, minähän myös osaan puhua proosaa!"

Surakan ja Laineen kirja on eri maata. He eivät pyrikään luomaan jotakin aivan uutta, vaan esittämään jäsentyneen kokonaiskuvan esimiestyön kentästä. Kirja on rajattu koskemaan lähiesimiehen työtä. Huomaa, että kirjoittajat ovat kokeneita esimiesten kouluttajia. He ovat ottaneet sisältöön paljon aineksia, joita käsitellään niin julkisen sektorin kuin yksityisen sektorinkin esimieskoulutuksissa.

Esipuheessa esitetään kirjan selkeä rakenne. Ensin esitetään teoriapohja esimiestyölle (luvut esimiestehtävästä, työelämän peruspsykologiaa yksilön ja ryhmän kannalta ja katsaus erilaisiin organisointitapoihin). Kun tietopohja on rakennettu, tarkastellaan oman johtajuuden rakentumista ja suunnittelun merkitystä. Sen jälkeen käsitellään käytännön päivittäisjohtamista monine haasteineen. Kirjassa esitellään hyödyllisiä, käytännönläheisiä malleja ja menettelytapoja esimiehen arkityöhön.

Kirja pyrkii nimensä mukaisesti olemaan käsikirja, ja siinä sen eräs ongelmallinen piirre onkin. Olisi melkoinen ihme, jos esimiestyön oleelliset seikat olisi saatu tungettua 204 sivuun. Osa luvuista on niin tiiviitä ja suppeita, että ne jäävät pintaraapaisuiksi tai käsitteen ohueksi esittelyksi (esimerkiksi suunnitteluun liittyvät osiot prosessien kehittämisestä tai talouden suunnittelusta). Hieman muista kirjoista poiketen oman esimiesroolin rakentumista käsitellään laajemmin, joka on mielestäni perustelua. Jotkut esitettävät mallit ovat hivenen vanhoja, kuten kirjoittajatkin toteavat (esimerkiksi niin sanottu Joharin ikkuna), mutta toimivat esimieskurssien keskustelun herättäjinä hyvin. Lopussa lueteltu lähdekirjallisuus on kuitenkin pääasiassa 2000-luvulta.

\section{KONFLIKTI ESIMIEHEN PÄÄNSÄRKYNÄ}

Kirjasta on pudotettu pois joitakin käytännön johtamistehtä- vien tarkastelua. Rekrytointia ei ole käsitelty vedoten siihen, että esimiehet eivät joudu sitä useinkaan tekemään. Toisaalta taitavasta ja ihmistä kunnioittavasta irtisanomistilanteen hoidosta on oma tekstinsä. En tiedä, mikä todellinen tilanne on, mutta oma tuntumani on, että rekrytointi on useammin toistuva tehtävä esimiesuralla kuin irtisanominen (tähän voi tulla kylläkin muutos nykyisessä taloustilanteessa ... ).

Konfliktien käsittelystä työyhteisössä on oma lukunsa. Ilmiö on esimiehen päänsärkynä sen verran yleinen, että teemaa on perusteltua käsitellä. Luvussa kuvataan myös ansiokkaasti käytännön menettelyitä konfliktien kesyttämiseksi. Konfliktien etenemistä käsittelevään kuvaan (s. 184) on jäänyt häiritsevästi viimeisiksi vaiheiksi seuraavat: strategisten toimintojen lamaantuminen, elintärkeiden toimintojen lamaantuminen ja viimeisenä vaiheena täysi sota tai joukkoitsemurha Työelämä on välillä rankkaa, mutta harvoin näin rankkaa.

Eräät uudemmat teemat tuntuvat unohtuneen kirjasta, kuten verkostoitumisen merkitys nykyisessä työelämässä. Verkostoitumista edellytetään nykyään myös lähiesimiehiltä ja aiheesta on kir 
joitettu viime vuosina todella paljon. Myös lähiesimiehiltä vaadittavaa strategiatyötä ja sen välineitä käsitellään melko vähän. Esimiesten suhde strategiaan ja strategiatyöhön on jännitteinen ja sitä on käsitelty monipuolisesti muualla (esimerkiksi Kimmo Suominen ja kumppanit 2009: Esimies strategiavaikuttajaksi). Ehkä aihe ei ole kirjoittajien lempilapsi ja sen käsittely on sen vuoksi saanut liian vähän huomiota (vain kaksi sivua!). Kirjassa viestitään mielestäni mallia, jossa esimiehen työ strategian suhteen olisi lähinnä strategian jalkauttamista, ei sen käsittämistä niinkään, vielä vähemmän siihen vaikuttamista.
Käytännön kouluttajana ja koulutussuunnittelijana ihailin kirjan jäsennystä. Teksti etenee teoriasta suunnittelun kautta käytännön johtamistilanteisiin. Teksti on sujuvaa ja selkeää, kaaviot ja kuvat selkeyttävät viestiä.

Teoksesta käy ilmi hyvin esimiestyön moninaisuus. Esimiestyö koostuu kahdesta pääkomponentista. Ne ovat tavoitteiden saavuttaminen ja työskentelevän ryhmän kannattelu ja ylläpito. Jokaisella esimiehellä on vahvuusalueensa ja kehitettävät puolet. Kirjan monipuolinen rakenne takaa sen, että jokainen aloittava esimies löytää siitä aineksia oman työnsä kehittämiseen. Luonteensa mukaisesti kirjaa voi varauksetta suositella esimiesuraansa aloittaville tai esimiesuraa harkitseville henkilöille. Jo kokeneemmat esimiehet etsivät ehkä mieluummin jo tiettyä aihealuetta syventävää kirjallisuutta.

Erityisen inspiroiva kirja on työelämän koulutussuunnittelijan näkökulmasta.

\section{Panu Savolainen}

psykologien lisensiaatti, työn ja organisaatioiden erikoispsykologi seniorikonsultti, Oiva-Akatemia Helsingin kaupunki 